\title{
Soil Quality and the Selection of Physicochemical Properties around Maro Rivers in Merauke Papua
}

\author{
Sumani $^{1}$, Supriyadi ${ }^{1}$, Siti Masiyah $^{2} \&$ Widya Aryani ${ }^{1}$ \\ ${ }^{1}$ Departmen of Soil Science, Sebelas Maret University, Surakarta, Indonesia \\ ${ }^{2}$ Water Resource Management, Musamus Merauke University, Papua, Indonesia \\ Correspondence: Supriyadi, Departmen of Soil Science, Sebelas Maret University, Surakarta, Jl. Ir. Sutami No \\ 36A, Jawa Tengah, 57126, Indonesia. E-mail: supriyadi_uns@staff.uns.ac.id
}

Received: July 29, 2020

Accepted: August 26, 2020

Online Published: August 31, 2020

doi:10.5539/mas.v14n9p69

URL: https://doi.org/10.5539/mas.v14n9p69

\begin{abstract}
Merauke Regency has 216.196 Ha of mangroves area which most of it was fed by the Maro River. The purpose of this research was to study the chemical, nutrient movement, and physiochemical properties by collecting the soil around the Maro River. 10 collected soil samples $(0-20 \mathrm{~cm}$ depth) were analyzed using standard methods. The result showed that the average CEC of soils around River Maro is $15.95 \mathrm{cmol} / \mathrm{kg}$. Organic matter and soil moisture content could be the contributor to enhance the CEC of soil. The average organic carbon was $1.34 \%$, while the BOD and COD were 2.44 and $5.70 \mathrm{mg} / \mathrm{L}$. Soil could have different mineralogical content which nutrient around Maro is decreasing due to waste disposal to the river, agricultural practice, and other human activities. Environmental management needs to reevaluate and studies about soil mineralogy strongly recommended.
\end{abstract}

Keywords: Maro, Merauke, physicochemical properties, rivers, soil

\section{Introduction}

One of the non-renewable natural sources is soil. Soil plays as s key role in life such as agriculture activities and the environment (Moraetis et al., 2016). With the increasing number of human activities, soil pollution is inevitable. The major causes of soil pollution were discharged of industrial waste, flows from solid waste landfills, percolation of contaminated water, or excessive use of pesticides or chemical fertilizers (Seifi et al., 2010). Waste from the industries or households that charged untreated flow into the various water sources and ended up in the coastal environment. This matter could lead to the changes in physicochemical properties of water bodies and soil which cause the undesirable transformation of the surrounding ecosystem.

Soil and water physicochemical properties were affected by some factors such as soil texture, $\mathrm{pH}$, cation exchange capacity (CEC), organic matter, and chemical properties of water. 5 to $7 \mathrm{pH}$ was the ideal condition for nutrient availability (Arp \& Krausse, 2006). Some soil chemical properties affect nutrient availability. Such as pH, organic matter, clay type and redox conditions. The chemical properties could transmitted easily from water to human through the food chain (Manga et al., 2017). Therefore, it is important to obtain ideal physicochemical properties in accordance with environmental purpose and agricultural needs.

The ecosystem is agriculture (Folack, 1997). Environment especially oil and water quality could be threatened by agro-establishment and bad agricultural practice by farmers such as excessive application of chemical fertilizers, insecticide, or herbicides. Unfortunately, the mangrove population in Merauke is decreasing because of the sand excavation and the use of mangrove as a construction material (Masiyah, 2016). Mangrove ecosystem is important for carbon sequestration (Twilley et al., 1992).

The mangrove ecosystem that was over-exploited and polluted pose as a threat (FAO, 2017). The increasing level of heavy metal in soil was once caused by the lithological or geogenic process but now due to human activities the increased heavy metal content also caused by the industrial process, agriculture, domestic house hold, or mining activity (Pam et al., 2013). Polluted soil or water will affect the living organism through the food chain (Mtunzi et al., 2015). Availability of heavy metal that could be absorbed into other living organisms depended on the soil properties, especially $\mathrm{pH}$ because it will affect their solubility and movement (Matthews-Amune \& Samuel, 2013).

One of the superior fishery products is mud crab (Scylla spp). This commodity has high potential in Merauke 
Regency and is the superior product in this district. Catching Scylla spp. is an object of livelihood for the Papuan people. The polluted mangrove ecosystem could reduce the population of Scylla spp. The purpose of this study was to compare the physicochemical properties of soils around Rivers Maro to soil quality and to propose some policies on soil management to optimize the potential sustainability of the mangrove crab resources through the ecological and sustainability studies of mangrove crab cultivation.

\section{Materials and Methods}

\subsection{Study Area}

The areas of the study were selected for five different locations of River Maro in Samkai village Merauke Regency (Figure 1). River Maro is a place for seekers of crabs (Scylla spp). The location of the sampling was in mangrove ecosystems, the current of the river, and the opposite of mangrove ecosystems. The five zones sampling located in mangrove Maro Arufua Merauke Regency; location 1; location 2; location 3; location 4; and location 5. Methods to use purposive sampling be based on the consideration location of Scylla spp. April to November was a time when the rainy season happened and December to March was the shorter dry season (Tening et al., 2013). Surface water samples were stored in clean bottles and kept immediately in a coolbox and transported to the laboratory for nutrient analysis.

\subsection{Sampling and Sampling Techniques}

Sampling was carried out within mangrove ecosystems, current of the river, and the opposite of mangrove ecosystems in April to November 2019. Sampling sites were set using a Global Positioning System (GPS). Soil sampling was from ten top soils samples with the depth around $0-20 \mathrm{~cm}$ and was collected using a spade around Maro Rivers. The samples dug out with spades and hand towels and immediately put them into a black polyethylene bag. After the samples were air-dried, they were sieved through a $2 \mathrm{~mm}$ sieve. Soil $\mathrm{pH}$ was measured with a pH meter. Organic carbon was estimated with the Walkley \& Black method (Black, 1965). Available phosphorus was determined by Bray-2 method (Bray \& Kurtz, 1945). CEC was determined by percolating $2.5 \mathrm{~g}$ of soil with $100 \mathrm{~mL}$ of $1 \mathrm{~N}$ ammonium acetate buffered at $\mathrm{pH} 7$. Total $\mathrm{N}$ was determined by the Kjeldahl method (Pauwels et al., 1992).

\section{Discussion}

Table 1. The result of analysis physicochemical properties in River Maro

\begin{tabular}{cccccccc}
\hline \multirow{2}{*}{ Sampling } & $\begin{array}{c}\text { Organic } \\
\text { Carbon }\end{array}$ & $\begin{array}{c}\mathrm{CEC} \\
(\mathrm{me} / 100 \mathrm{gr})\end{array}$ & $\mathrm{BOD}(\mathrm{mg} / \mathrm{L})$ & $\mathrm{COD}(\mathrm{mg} / \mathrm{L})$ & $\mathrm{K}_{2} \mathrm{O}$ & $\mathrm{P}_{2} \mathrm{O}_{5}(\mathrm{mg} / \mathrm{g})$ & Total N (\%) \\
\hline Location 1 & 1,67 & 16,87 & 2,4 & 5,45 & 8,2 & 11,4 & 0,255 \\
& 1,31 & 15,67 & 2,6 & 6,11 & 7,0 & 12,9 & 0,693 \\
Location 2 & 0,86 & 14,39 & 2,5 & 5,86 & 4,7 & 17,2 & 0,115 \\
& 0,81 & 15,24 & 2,3 & 4,98 & 5,1 & 15,9 & 0,346 \\
Location 3 & 1,15 & 13,17 & 2,8 & 5,56 & 5,4 & 13,0 & 0,115 \\
& 1,39 & 13,50 & 2,5 & 6,66 & 8,1 & 27,7 & 0,354 \\
Location 4 & 1,27 & 17,96 & 2,4 & 6,12 & 7,0 & 24,0 & 0,468 \\
& 1,43 & 15,36 & 2,6 & 5,85 & 8,2 & 7,8 & 0,116 \\
Location 5 & 0,93 & 22,45 & 2,2 & 4,85 & 8,6 & 17,6 & 0,641 \\
& 2,65 & 14,95 & 2,1 & 5,57 & 7,2 & 11,4 & 0,465 \\
\hline
\end{tabular}



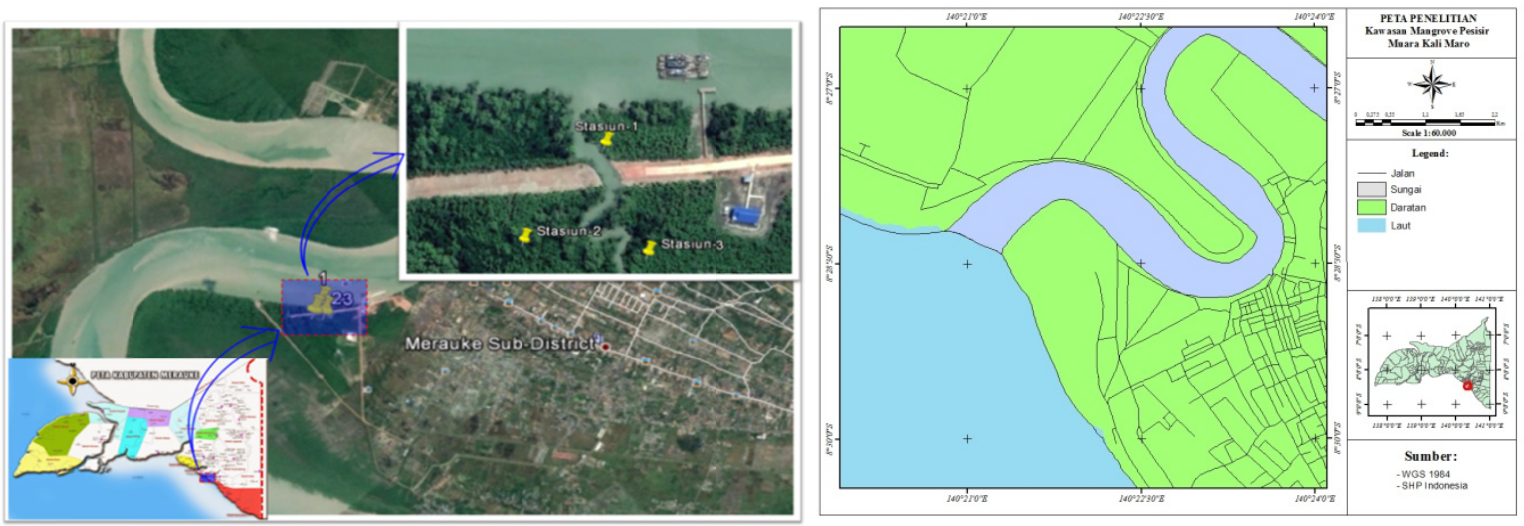

Figure 1. Map of research area

The most important factor in the distribution of crab-diversity in the past and future is climate change (Vernberg et al., 1970; Peterson et al., 1987; Root et al., 2003; Rosenzweig et al., 2008). Environmental factors have strongly related to crab life (Macpherson, 2002; Hiddink et al., 2008). Biodiversity crab can be caused by eutrophication (Elmanama et al., 2006). This research is an agreement with earlier studies. Organic waste dump in coastal waters will affect the diversity of crabs and other important crustacean fisheries. The waste dump will affect the physicochemical parameters that important to Scylla spp. The changes directly affect their growth, metabolism, hormone, and oxygen consumption (Chen et al., 1995; Madesani et al., 2001).

Rainfall is a key role in the distribution of aquatic animals. The substance of rainfall could bring chemical dissolved and toxic gases that were present in the air. The mangrove, the coral reef can be contaminated due to raining activities (Lipp et al., 2001; Boehm et al., 2002). Phosphate loaded mud with a huge volume that increased from agricultural land could be carried out by raining activities. It makes different temperatures, salinity, and turbidity as the importance of Scylla spp. abundance Ryther et al., 1966).

Salinity is likely to influence the distribution of Scylla spp. and other living organisms (Chandra et al., 1998). High salinity was found in summer than monsoon season. The trawl catches and salinity have direct relationship temperature as well as plankters and inverse relationship between the rainfalls and trawl catches. Causative factors could be the lower temperature and salinity condition (Sudarman, 1985).

Potential hydrogen was also an important parameter that affects the distribution and diversity of Scylla spp. This parameter can be increased with process photosynthesizing organism especially phytoplankton from the sea. Photosynthetic activity, biology activity, and seawater penetration could be the influence of the activities (Das et al., 1997). The peak monsoon season has quite low during floods such as decomposition of organic matter, reduction salinity, and temperature (Zhingde et al., 1988). The high $\mathrm{pH}$ or categorized in alkaline $\mathrm{pH}$ has more number of crab species. Physiology, maturation process, and metabolism in crabs were affected by $\mathrm{pH}$ (Muthu et al., 1977).

Another important parameter in the aquatic ecosystem is dissolved oxygen (Das, 2000). Dissolved oxygen shows sufficient oxygen in the water. Pollution caused low dissolved oxygen in the water. Imbalance crab communities also could be caused by a high nutrient level in the water. Crab's behavior and life strategies were influenced by the concentration of dissolved oxygen and energy content (DelValls et al., 1998). In the summer season when temperature and salinity of water increased, dissolved oxygen was decreased (Nas \& Nas, 2009). Low dissolved oxygen in the study area because of the lesser input of freshwater.

Crab's growth was influenced by food material and the transport of oxygen. Several authors have been reported about the crab's oxygen consumption. The rates of respiration can influence the metabolism in crabs and anaerobic metabolism. This process will reduce growth and molting frequency, reduction of metabolic rate, and change in crab's hemolymph osmotic pressure (Charmantier-Daures et al., 1994). Not only the environment, but soil properties such as plankters, organic matter, and organisms could also cause turbidity in water which limiting crabs' production in water bodies. Water turbidity will decrease water clarity and reduce the availability of light for photosynthesis (Miner et al., 1996).

Low BOD value in sampling area was caused by the monsoon season that indicates the assimilation of organic load. The oxygen that was utilized by microorganisms to stabilize organic water is biochemical oxygen. In crab, biochemical oxygen was used to help oxygen uptake and consumption. This response changes in environmental 
salinity. The population of Paleamonetes antennarium was revealed by Giuseppe caused by salinity and temperature of freshwater oxygen consumption (Miner et al., 1996).

COD is an oxygen equivalent organic matter of water which is susceptible by the strong chemical oxidant. The summer season has maximum COD values because the inflow of land waste is decreasing which leads to an increase in salinity, plankters productivity, salinity, and microbes' oxygen utilization. Monsoon season where heavy rain runoff increasing the amount of land waste into the coast has minimum value of COD (Das et al., 1997). Another effect is decreased biology activity caused by salinity and temperature. To assess water pollution, COD a reliable parameter (Das et al., 1997).

During monsoon season, the marine ecosystem which generally nitrogen-limited has high concentration of nitrate due to wastes and heavy rainfall (Anbazhagan, 1998). Habitat loss, alga blooms, decreased biodiversity, oxygen deficiency and fishery loss were caused by excessive nitrogen input that leads to degradation of water quality (Vasantha, 1989). The decreasing water flow and high population density during summer were caused by minimum nitrate by phytoplankton utilization. Ammonia oxidation, nitrate reduction, planktonic excretion increase in water was due to bacterial decomposition which leads to higher nitrate value in November or during monsoon season. (Jayaprakash et al., 2005).

\section{Conclusion}

This study investigated the physicochemical properties from Scylla spp. in which the waste is discarded without being used and causes environmental pollution. Although physicochemical properties showed a high ability for more diversity of crabs. The good environmental properties can be made biodiversity of crabs. It is make to influence farmer fishing to get a high salary. The reducing power physicochemical properties were high but low in the crab's activity and ability. Research related to physicochemical properties that are suitable for living conditions and could increase the crab's abundance can be done further.

\section{References}

Anbazhagan, P. (1998). Hydrobiology and benthic ecology of Kodiakkarai coastal sanctuary (Southeast coast of India). Ph.D. Thesis. University of Annamalai, Tamil Nadu, India.

Arp P. A., Krausse H. H. (2006). Forest Soils Properties and Productivity. Encyclopedia of Soil Science, 2(10), 1081.

Black, C.A. (1965). Methods of Soil Analysis, Part 2, Agronomy 9. American Society of Agronomy: Madison,Wis. https://doi.org/10.2134/agronmonogr9.1

Boehm A. B., Grant S. B., Kim J. H., Mowbray S. L., McGee C.D., Clark D., ... Wellman D. E. (2002). Decadal and shorter period variability of surf zone water quality at Huntington Beach, California. Environmental Science Technology, 36, 3885-3892. https://doi.org/10.1021/es020524u

Bray, R. H., Kurtz L. T. (1945). Determination of total organik and available forms of phosphorus in soils. Soil Science, 59, 39 - 45. https://doi.org/10.1097/00010694-194501000-00006

Chandra M. P., Sreenivas N. (1998). Diel variations in zooplankton populations in mangrove ecosystem at Gaderu canal, Southeast coast of India. Indian Journal of Geo-Marines Science, 27, 486-488.

Charmantier-Daures M., Charmantier G., Janssen K. P. C., Aiken D. E., Van Herp, F. (1994). Involvement of eyestalk factors in the neuroendocrine control of hydromineral metabolism in adult American lobster Homarus americanus. General and Comparative Endocrinology, 94(3), 281-293. https://doi.org/10.1006/gcen.1994.1085

Chen S., Wu J., Huner J.V., Malone R.F. (1995). Effects of temperature upon ablation-to-molt interval and mortality of red swamp crawfish (Procambarus clarkii) subjected to bilateral eyestalk ablation. Aquaculture, 138, 191-204. 25. https://doi.org/10.1016/0044-8486(94)00327-K

Das A. K. (2000). Limno-Chemistry of some andhra pradesh reservoirs. Journal of the Inland Fisheries Society of India, 32.

Das J., Das S. N., Sahoo R. K. (1997). Semidiurnal variation of some physicochemical parameters in the Mahanadi estuary, East coast of India. Indian Journal of Geo-Marines Science, 26, 323-326.

DelValls T. A., Forja J. M., Gomez-Parra A. (1998). The use of multivariate analysis to link sediment contamination and toxicity data to establish sediment quality guidelines: An example in the Gulf of Cadiz (Spain). Ciencias Marina, 24(2), 127-154. http://dx.doi.org/10.7773/cm.v24i2.1207

Elmanama A. A., Afifi S., Bahr S. (2006). Seasonal and spatial variation in the monitoring parameters of Gaza 
Beach during 2002-2003. Environmental Research, 101, 25-33. https://doi.org/10.1016/j.envres.2005.07.005

Folack, J. (1997). Coastal Erosion Problems in Cameroon: Mitigating Measures and Control Strategies. Paper presented at International Conference on Integrated Coastal Zone Management, Boston, Massachusetts.

Food and Agriculture Organization of the United Nations - FAO. (2007). Mangrove Assessment Study. The World's Mangroves 1980-2005. Rome, Italy: FAO Forestry Paper 153.

Hiddink J. G., Ter Hofstede R. (2008). Climate induced increases in species richness of marine fishes. Global Change Biology, 14, 453-460. https://doi.org/10.1111/j.1365-2486.2007.01518.x

Jayaprakash M., Srinivasalu S., Jonathan M. P., Mohan V. R. (2005). A baseline study of physico-chemical parameters and trace metals in waters of Ennore Creek, Chennai, India. Mar Pollut Bull, 50, 583-589. https://doi.org/10.1016/j.marpolbul.2005.01.021

Kishore K., Joshi B. D., Deepali K. (2005). Physicochemical characteristics of pond water at Kanpur village in Bareilly district (UP). Him J Environ Zool, 19, 89-92.

Lipp E. K., Farrah S. A., Rose J. B. (2001). Assessment and impact of microbial fecal pollution and human enteric pathogens in a Coastal Community. Mar Pollut Bull, 42, 286-293. https://doi.org/10.1016/s0025-326x(00)00152-1

Macpherson E. (2002). Large-scale species-richness gradients in the Atlantic Ocean. Proceedings of the Royal Society B: Biological Sciences, 269(1501), 1715-1720. https://doi.org/10.1098/rspb.2002.2091

Manga V. E., Neba G. N., Suh C. E. (2017). Environmental geochemistry of mine tailings soils in the artisanal gold mining district of Bétaré-Oya, Cameroon. Environmental and Pollution, 6(1), 52-61. https://doi.org/10.5539/ep.v6n1p52

Masiyah S. (2016) Biodiversitas Mangrove di Kabupaten Merauke Provinsi Papua. Jurnal Ilmiah Agribisnis dan Perikanan, 9(1), 1-7. https://doi.org/10.29239/j.agrikan.10.1.1-7

Matthews-Amune O. C., Samuel K. (2013). Investigation of heavy metal levels in roadside agricultural soil and plant samples in Adogo, Nigeria. Academia Journal of Environmental Sciences, 1(2), 031-035. http://dx.doi.org/10.15413/ajes.2012.0123

Medesani D. A., López G. L. S., Rodríguez E. M. (2001). Effects of cadmium and copper on hormonal regulation of glycemia by the eyestalks in the crab Chasmagnathus granulata. Bulletin of Environmental Contamination and Toxicology, 66, 71-76. https://doi.org/10.1007/s0012800207

Miner J. G., Stein R. A. (1996). Detection of predators and habitat choice by small bluegills: effects of turbidity and alternative prey. Journal of Transaction of the American Fisheries Society, 125, 97-103. https://doi.org/10.1577/1548-8659(1996)125<0097:DOPAHC >2.3.CO;2

Moraetis D., Simantiris N. L., Pentari D., Manoutsoglou E., Apostolaki C., Perdikatsis V. (2016). Chemical and Physical Characteristics in Uncultivated Soils with Different Lithology in Semiarid Mediterranean Clima. Applied and Environmental Soil Science, 29, 1-13. https://doi.org/ 10.1155/2016/3590548

Mtunzi F., Dikio E. D., Moja S. (2015). Evaluation of Heavy Metal Pollution on Soil in Vaderbijlpark, South Africa. International Journal of Environmental Monitoring and Analysis, 3(2), 44-4. https://doi.org/10.11648/j.ijema.20150302.13

Muthu M. S., Laxminarayana A. (1977). Induced maturation and spawning of Indian penaeid prawns. Indian Journal of Fisheries, 24, 172-180.

Nas S. S., Nas E. (2009). Water Quality Modeling and Dissolved Oxygen Balance in Streams: A Point Source Streeter-Phelps Application in the Case of the Harsit Stream. CLEAN - Soil, Air, Water, 37(1), 67-74. https://doi.org/10.1002/clen.200800107

Pam A. A., Sha'Ato R., Offem J. O. (2013). Evaluation of heavy metals in soils around auto mechanic workshop clusters in Gboko and Makurdi, Central Nigeria. Journal of Environmental Chemistry and Ecotoxicology, 5(11), 298-306. https://doi.org/10.5897/JECE2013.0295

Pauwels J. M., Van R. E., Verloo M., MvondoZe A. (1992) Manuel de laboratoire de pedologie. Public. Agric, 28, $75-126$

Peterson B. J., Howarth R. W. (1987). Sulfur, carbon, and nitrogen isotopes used to trace organic matter flow in the salt-marsh estuaries of Sapelo Island, Georgia. Limnology and Oceanography, 32(6), 1195-1213. 
https://doi.org/10.4319/lo.1987.32.6.1195

Root T. L., Price J. T., Hall K. R., Schneider S. H., Rosenzweig C., Pounds A. (2003). Fingerprints of global warming on wild animals and plants. Nature, 421, 57-60. https://doi.org/10.1038/nature01333

Rosenzweig C., Karoly D., Vicarelli M., Neofotis P., Wu Q., ... Imeson A. (2008). Attributing Physical and Biological Impacts to Anthropogenic Climate Change. Nature, 453, 353-357. https://doi.org/10.1038/nature06937

Ryther J. H., Hall J. R., Pease A. K., Bakun A., Jones M. M. (1966). Primary organic production in relation to the chemistry and hydrography of the western Indian Ocean. Limnology and Oceanography, 11, 371-380. https://doi.org/10.4319/lo.1966.11.3.0371

Seifi M. R., Alimardani R., Sharifi A. (2010). How can Soil Electrical Conductivity Measurements Control Soil Pollution?. Research Journal of Environmental and Earth Sciences, 2(4), 235-238.

Sudarsan D. (1985). Results of exploratory survey around the Andaman Islands. Bulletin of the Exploratory Fisheries Project, 7, 1-43.

Tening A. S., Chuyong G., Asongwe G. A., Fonge B. A., Lifongo L. L., ... Suh C. E. (2013). Contribution of some water bodies and the role of soils in the physicochemical enrichment of the Douala-Edea mangrove ecosystem. African Journal of Environment and Science Technology, 7(5), 336-349. https://doi.org/10.5897/AJEST12.081

Twilley R. R., Chen R. I., Hargis T. (1992). Carbon Sinks in Mangroves and Their Implications to Carbon Budget of Tropical Coastal Ecosystems. Water Air and Soil Pollution, 64(1), 265-288. https://doi.org/10.1007/BF00477106

Vasantha K. (1989). Studies on hydrobiology and decomposition of macrophytes in Portonovo marine environment Southeast coast of India. Ph.D. Thesis. University of Annamalai, Tamil Nadu, India.

Vernberg F. J., Vernberg W. B. (1970). Lethal limits and the zoogeography of the faunal assemblages of coastal Carolina waters. Marine Biology, 6, 26-32. https://doi.org/10.1007/BF00352604

Zhingde M. D., Nair R. V., Govindan K., Sabnis M. M. (1988). Marine environmental impact assessment of proposed tidal power development in the Gulf of Kutch. Proc Symp on tidal power plant development in the Gulf of Kutch, Central Electricity Authority, New Delhi 205-208.

\section{Copyrights}

Copyright for this article is retained by the author(s), with first publication rights granted to the journal.

This is an open-access article distributed under the terms and conditions of the Creative Commons Attribution license (http://creativecommons.org/licenses/by/3.0/). 